\title{
Ratlarda Postnatal Dönemde Testis Dokusu ile Kan Testis Bariyerinin Gelişiminin Histomorfometrik ve İmmunohistokimyasal Değerlendirilmesi
}

\author{
Histomorphometric and immunohistochemical evaluation of the testes and blood-testis
}

\author{
barrier in postnatal period in rats.
}

\author{
Prof. Dr. Ahmet SONGUR', Hüsniye KARATEKE ${ }^{1}$, Prof. Dr. Murat TOSUN², Yrd. Doç. Dr. Yücel GÖ- \\ NÜL ${ }^{1}$, Yrd. Doç. Dr. Ozan TURAMANLAR' \\ 'Afyon Kocatepe Üniversitesi Tıp Fakültesi Anatomi Anabilim Dalı, Afyonkarahisar \\ 'Afyon Kocatepe Üniversitesi Tıp Fakültesi Anatomi Anabilim Dalı, Afyonkarahisar \\ ${ }^{2}$ Afyon Kocatepe Üniversitesi Tıp Fakültesi Histoloji ve Embriyoloji Anabilim Dalı, Afyonkarahisar \\ ${ }^{1}$ Afyon Kocatepe Üniversitesi Tıp Fakültesi Anatomi Anabilim Dalı, Afyonkarahisar \\ ${ }^{1}$ Afyon Kocatepe Üniversitesi Tıp Fakültesi Anatomi Anabilim Dalı, Afyonkarahisar
}

\begin{abstract}
öz
Amaç: Erkek üreme sisteminin temel görevi sperm üretip, oluşturduğu bu spermleri dişi vajinasına iletmeye yardımcı olmaktır. Bu süreçte, testisler, sperm ve primer erkek cinsiyet hormonu olan testosteronu üretirken; yardımcı kanallar, testislerdeki ya da yardımcı bezlerdeki salgıları depolayıp penis'e taşırlar. Çalışmamızın amacı; testislerin histomorfolojik olarak doğum sonrası dönemdeki farklı gelişim zamanlarında incelenmesini sağlamak ve Sertoli hücrelerinin oluşturduğu kan-testis bariyerinin gelişimin hangi döneminde oluştuğunu saptamaktır.
\end{abstract}

Gereç ve Yöntem: Çalışmamızda postnatal dönemde bulunan 14., 30., 60. ve 90. günlerde Sprague-Dawley türü 24 erkek rat kullanıldı. Elde edilen testis kesitleri hemotoksilen-eozin ile Cadherin ve Claudin immun boyaları ile boyanarak kan-testis bariyerinin gelişimi ve histolojik yapılanması değerlendirildi. Ayrıca testislerin diğer bileşenleri olan spermatogoniumların, Sertoli hücrelerinin ve Leydig hücrelerinin gelişimi ile organizasyonu değerlendirildikten sonra gelişimsel süreçte seminifer tübüllerin histomorfolojik anlamda geçirmiş olduğu değişiklikler belirlendi.

Bulgular: Elde edilen sonuçlara göre ratlarda sperm üretim sürecinin intrauterin hayatta başlamadığı ve hatta doğum sonrası 14. günde bile mevcut olmadığı görülmüştür.

Sonuç: 30 . günden kısa süre önce başladığını düşündüğümüz spermatogenetik sürecin yaşa bağımlı bir paralellik gösterdiği ortaya konmuş olup kan-testis bariyerinin varlığı ile birlikte fonksiyonel anlamda testis yapılanmasının 60 günlük ratlarda mevcut olduğu tespit edilmiştir. Bununla birlikte elde edilen bu yapılanma bulgularının ilerleyen günlerde fazla değişiklik göstermediği de belirlenmiştir.

Anahtar kelimeler: Morfometri; Kan-testis bariyeri; İmmünohistokimya; Sertoli hücreleri; Spermatogenezis

\section{ABSTRACT}

Objective: The main function of male reproductive system is not only to produce sperms but also to transfer these sperms to female vajina. While testes produce sperm and testosterone, the primary male sex hormone, accessories ducts store the secretions located in testes or accessories glands and they transport these secretions to penis. The aim of our study is to examine the testes histomorphologicaly at different developmental stages after the post natal period and also to determine the period in which the development of blood-testis barrier formed by Sertoli cells was accomplished.

Material and Methods: 24 Sprague-Dawley types of male rats which are during the postnatal period in the 14th, 30th, 60th and 90 days were used in this study. The development and histological structure of blood-testis barrier were investigated by labeling the obtained testes sections using hematoxylin-eosin dyes and also cadherin and claudin primary antibodies. Furthermore, after the examination of the development and organization of the other components of testis which are spermatogoniums, sertoli and Leydig cells, the changes were histomorphologically determined in the seminiferous tubeles at the developmental stages.

Results: According to the obtained results on rats, the sperm production process do not start in utero life and even the sperm production do not take place at 14 th day after the birth.

Conclusion: We thought that spermatogenetic process started less than 30 days ago and it depends on the age. On the other hand, the existence of blood-testis barrier enable us to detect the functional testis settlement in 60 days rats. Besides, the obtained settlement findings did not show significant difference in the upcoming days.

Key Words: Morphometry; Blood-testis barrier; Immunohistochemistry; Sertoli cells; Spermatogenesis. 


\section{GíRiş}

Yüzyıllardır insanoğlu gerek kendi ve gerekse çevresindeki canlıların yaşam döngülerini incelerken bunların içinde genital sistemin incelenmesi her zaman diğer sistemlerden ayrı bir yerde tutulmuş ve daha detaylı olarak çalışılmıştır. İnsanoğlu canlı bedeninin nasıl oluştuğu sorusuna her dönem cevap ararken üreme için gerekli hücrelerin büyüklükleri, şekilleri gibi yapısal özellikleri yanında bu hücrelerin kolayca, hatta bazı canlılarda makroskopik düzeyde elde edilebilmesi ve bu hücreler üzerinde manipülasyon yapılabilme esnekliğinin fazla olması bu konulara ilgiyi daha çok arttırmıştır. Diğer yandan toplumsal ve etik sınırlamalardan dolayı bu konularda yapılan çalışmalar halen istenildiği düzeyde değildir. Literatürdeki mikroskobik veya makroskobik çalışmaların çoğu insan dışı canlılara ait olduğu için elde edilen veriler çoğu kez insanlar için uyarlanarak belli hipotezler oluşturabilmeyi sağlama, bunları destekleme veya çürütme ötesinde amaçlara hizmet edememektedir. Bununla birlikte dünya üzerinde az sayıda olsa da oldukça gelişmiş fetüs koleksiyonuna sahip merkezlerde insana yönelik çaIışmalar belli bir düzeyde devam etmektedir. Hatta son yıllarda geliştirilen değişik immunohistokimyasal boyama, PCR ve Western blotting gibi moleküler teknikler tek bir embriyo veya fetusta eş zamanlı ve çok sayıda değişimler hakkında güvenilir bilgiler vermektedir. Bu bilgilerin günümüzde sadece bilimsel anlamda veriler olması yanında embriyolojik gelişim sürecinde görülen hastalıkların erken tanısı, teratolojik ajanların etkilerinin belirlenmesi gibi önemli klinik hizmetlere yardımcı olmaktadır.

Erkek ratlarda spermatogenezis, puberte döneminde görülen fizyolojik değişikliklerden bir tanesidir. Her ne kadar seminifer tübüllerde tek bir somatik hücre olarak Sertoli hücreleri olsa da farklı tipte germ hücre serilerinin olması oldukça önemlidir (1). Bu hücreler içinde uzamış veya yuvarlak spermatidler, pakiten veya preleptoten spermatositler ile A ve B tipi spermatogoniumlar bulunur. Puberteye kadar sadece seminifer tübüllerin bazal membranlarında mayoz bölünmeye girmeden bekleyen A tipi spermatogonialar bu dönemde testosteron salgılanmasında görülen artış ile uyarılarak bölünmelerine başlarlar ve B tipi spermatogonialara dönüşürler spermiyogenez süreci içinde mayoz bölünmelerini tamamlayarak ergin sperm haline gelirler. Epididimis içinde olgunlaşan ve fertile hale gelen spermatozoalar oositi dölleme yeteneğine sahip olurlar. Bu süreçte tüm spermatozoalarda çok sayıda hormonal, yapısal ve ayrıca sitoplazmik ve moleküler değişiklikler görülür (2).

Testislerin histomorfolojik özellikleri genel ışık mikroskobik incelemelerde daha çok spermatogenezisin değerlendirilmesinde kullanılırken, fonksiyonel anlamda, çok bilgi verici değildir. Bununla birlikte, moleküler düzeyde yapılan incelemelerde tübül içinin apayrı bir yapılanma gösterdiği ve tüm testisi oluşturan tübüllerin arasında bile farklılıklar olduğu tespit edilmiştir (3). Bu yapılanmalar içinde belki de en önemli organizasyon tübül içinde yer alan Sertoli hücreleri ile spermatogonialar arasında oluşturulan kan-testis bariyeridir. Bu bariyer oldukça antijenik karakterde olan spermatogoniaların kan ile irtibatını kesmek suretiyle immun sistem içinde spermatogonialara karşı bir antikor oluşumunu yani otoimmun cevabı engeller $(4,5)$. Ancak kan-testis bariyeri tam anlamıla fonksiyonel bir bariyer değildir ve fonksiyonel kan-testis bariyerinin Sprague-Dawley cinsi ratlarda doğum sonrası 20. güne kadar kurulamadığı gösterilmiştir (6).

Çalışmamızın amacı erkek genital sisteminin temel öğelerinden biri olan testislerin histomorfolojik olarak doğum sonrası dönemde farklı periyodlarda gelişimlerini ve kan testis bariyerinin oluşumu belirlemek ve değerlendirmektir. Bu amaçla doğum sonrası 14 günlük, 30 günlük, 60 günlük ve 90 günlük ratlarda testislerin yapısını oluşturan seminifer tübül gelişimi, spermatogoniaların gelişimi ve farklılaşması, Leydig ve Sertoli hücrelerinin varlığı ve dağılımı ve kan testis bariyerinin oluşumu histokimyasal ve immunohistokimyasal olarak boyandıktan sonra ışık mikroskobunda incelenip değerlendirilmiştir.

\section{GEREÇ VE YÖNTEM}

Etik Kurul; Afyon Kocatepe Üniversitesi Hayvan Etik Kurulu'ndan etik çalışma onayı (AKÜHADYEK-158-12) alındı. 
Deney Hayvanları ve Deney Grupları; Çalışmamizda toplam 24 adet Sprague-Dawley tipi erkek ratlar kullanılmış olup bu hayvanlar öncelikle yaş gruplarına göre 4 gruba ayrılmıştır. Hayvanlar aşağıdaki şekilde gruplanmıştır;

\section{Grup 1. Prepubertal dönemdeki (14 günlük) ratlar}

Grup 2. Erken Pubertal dönemdeki (30 günlük) ratlar

Grup 3. Geç Pubertal dönemdeki (60 günlük) ratlar

Grup 4. Ergin (90 günlük) ratlar

Deney; Cerrahi işlemden 12 saat önceden itibaren aç bırakılan ratlar, $21 \pm 1{ }^{\circ} \mathrm{C}$ sıcaklık ve $\%$ 45-55 nem olan ortamda 12/12 saat ışık siklusu göz önünde bulundurulacak şekilde polikarbonat kaplarda Afyon Kocatepe Üniversitesi Deney hayvanları ünitesinde büyütüldü ve beslendi ayrıca operasyon öncesi özel odaya alındı. Burada 2 saat kadar ortama adaptasyon için beklendikten sonra herhangi bir kimyasal ajan verilmeksizin hayvanlara anestezi uygulandı. Anestezi için ksilazin $87 \mathrm{mg} / \mathrm{kg}$ im ve ketamin $13 \mathrm{mg} / \mathrm{kg}$ im uygulandı. Anesteziyi takiben, sıçanlar olası ani hareketleri ile sterilizasyonu bozmaması için ekstremitelerinden ameliyat masasına bağlandı. Batın tıraş edilip, povidone-iodine solüsyonu ile silindikten sonra steril koşullarda, median laparatomi ile açıldı, Anestezi sonrasında sırtüstü yatırılan ratların alt abdominal bölgesine kesi uygulanarak bu bölgeden her iki testis çıkartıldı. Eksizyonla alınan dokular histolojik doku takibi sırasında fiksasyon sağlamak için Bouin solüsyonu içine konuldu. Başkaca bir işlem uygulanmayan hayvanlar eksizyon sonrası sakrifiye edilerek özel atık poşetleri ile deney hayvanları ünitesine teslim edilerek yok edilmeleri sağlandı.

Histolojik Değerlendirme; Alınan testisler Bouin fiksatifi içine konduktan sonra dokunun büyüklüğüne paralel olacak şekilde 3-5 gün fikse edildi. Fiksasyon sonrası rutin histolojik doku takip metodu ile testisler parafin bloklara gömüldü. $\mathrm{Bu}$ bloklardan $5 \mu$ kalınlığında kesitler histokimyasal boyama için klasik lam üstüne, immunohistokimyasal boyama için polilizinli lamlar üzerine alındı. Alınan örnekler deparafinize edildikten sonra histokimyasal olarak Hema-
toksilen-Eozin ve immunohistokimyasal olarak Pan-Cadherin (Thermo Scientific, Fremont, CA, USA) Labvision, ve Claudin 1 (Thermo Scientific, Fremont, CA, USA) ile boyandı. Histokimyasal olarak dokuların değerlendirilmesi Nikon E600-Japan ışık mikroskobu altında ve Nikon Digital Sight-DS-L1 Image Analysis software kullanılmak suretiyle yapıldı. İmmunohistokimyasal inceleme sırasında immunopozitif alanlar aynı ışık mikroskobu ile incelenerek Kan Testis bariyerinin gelişimi ile ilgili değerlendirmeler yapıldı. Bu incelemeler ile ilgili detaylar aşağıda verilmiştir.

Görüntü Analizi; Yapılan histokimyasal boyamalarda boyanan testis dokularında mevcut seminifer tübüllerin çapları Nikon Digital Sight-DS-L1 Image Analysis software ile ölçüldü. Ölçüm sırasında her bir rata ait testis dokusundan alınan kesitlerden, $x 20$ objektif büyütmede, farklı alanlardan 20'şer olmak üzere toplam 120 seminifer tübül çapı ölçüldü. Ölçüm sırasında kesit düzlemi yuvarlak veya hafif oval olan tübüllerin çapları ölçüldü. Elde edilen değerler istatistiksel analiz için kullanıldı.

Istatistiksel Analiz; Image Analysis Software ile ölçülen seminifer tübül çaplarına ait veriler, SPSS for Windows 16.0 paket istatistik programında analiz edildi. Analiz için Oneway ANOVA metodu kullanıldı. PostHoc testi olarak Tukey HSD testi kullanıldı. P değeri 0.05 'den küçük olan değerler istatistiksel olarak anlamlı kabul edildi.

\section{BULGULAR}

Yapılan histolojik değerlendirmelerde 4 gruba ait testislerin incelemelerinde seminifer tübüllerin çapları, içlerindeki hücrelerin varlığı ve dağılımı yanında kan-testis bariyerinin varlığı ve yapılanması yorumlanmış ve bu verilere göre aşağıdaki bulgular elde edilmiştir.

Seminifer tübüllerin histolojik değerlendirilmesi; Yapılan değerlendirmelerde tüm yaş gruplarındaki ratların testislerinde seminifer tübüle ait histolojik komponentlerin yani spermatogoniaların, Sertoli hücrelerinin ve seminifer tübül dışındaki intertübüler alanda Leydig hücrelerinin ve bağ dokusu hücrelerinin mevcut olduğu 
tespit edildi. Bununla birlikte, 14 günlük ratlara ait testislerden alınan kesitler mikroskobik olarak incelendiğinde soluk renkli sitoplazmalarıyla Sertoli hücrelerinin daha yoğunlukta olduğu spermatogonia sayısının az olduğu ve hiç spermatid olmadığı gözlendi. Ayrıca tübüllerin büyük kısmında lümenin şekillenmemiş olduğu görüldü. Intertübüler alanda ise seyrek de olsa Leydig hücreleri görülmekteydi (Resim:1A).

Diğer yandan 30 günlük ratlara ait testislerden alınan kesitlerin mikroskobik incelenmesinde seminifer tübüllerin organizasyonunun gelişmiş olduğu tübül çaplarının arttığı, tübül içinde

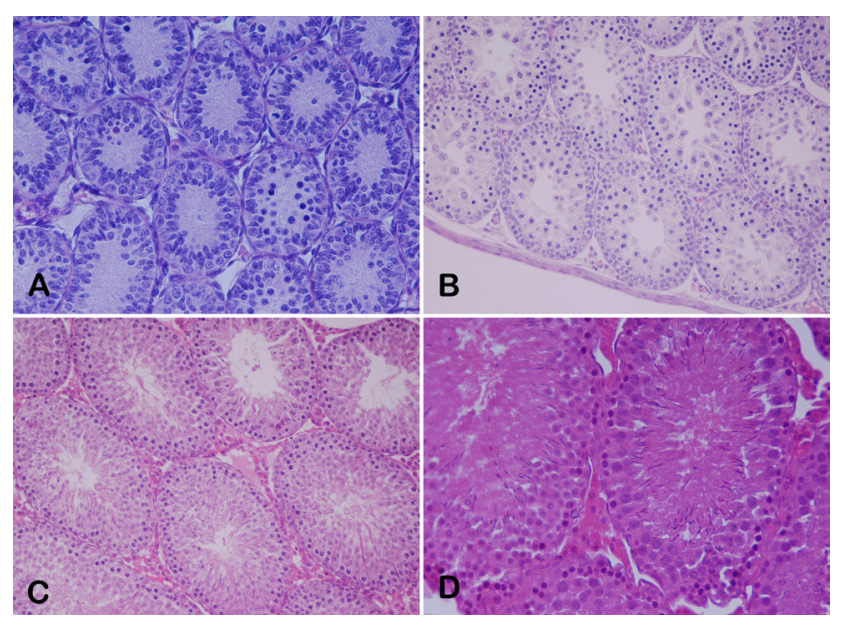

Resim 1: A. 14 günlük rat testislerinin genel histolojik görünümü (Hematoksilen-eozin, x40). B. 30 günlük rat testislerinin genel histolojik görünümü (Hematoksilen-eozin, x40). C. 60 günlük rat testislerinin genel histolojik görünümü (Hematoksilen-eozin, x40). D. 90 günlük rat testislerinin genel histolojik görünümü (Hematoksilen-Eozin, x60).

A ve $B$ tipi spermatogoniaların belirgin derecede arttığı ve Sertoli hücrelerinin ayrımının güçleştiği tespit edildi. Bununla birlikte oldukça az sayıda spermatid olduğu lümene yakın bölgede tip B spermatogoniaların daha yoğun olduğu gözlendi. İntertübüler alanda ise Leydig hücre sayısında artış dikkati çekmekteydi. Ayrıca tunica albuginea'nın sıkı bağ dokusu özelliğinde yapılandığı dikkati çekti (Resim:1B).

Altmış günlük ratların testislerinin incelenmesinde ise testislerin tam organize bir yapılanma içinde olduğu, seminifer tübüllerin bol miktarda spermatogonialar ve spermatidlerle dolu olduğu tespit edildi. Sertoli hücrelerinin seçilmesinin oldukça zorlaştığı belirlendi. Tübül çaplarının oldukça artmış olduğu ve lümenlerinde belirgin derecede genişlemiş olduğu tespit edildi. Intertübüler alanda Leydig hücre sayısı- nın belirgin derecede arttığı ve bağ dokusunun gelişmiş olduğu tespit edildi (Resim:1C).

Doksan günlük ratların testislerinin incelemesinde ise histolojik organizasyonun 60 günlük rat testislerine benzer olduğu görüldü. Spermatogoniaların sayısının oldukça fazla olduğu lümen çapının iyice genişlemiş olduğu, Sertoli hücrelerinin iyice seçilemez hale geldiği ve lümenin iç kısmına kadar spermatidlerin bolca dağılmış halde olduğu gözlendi. İntertübüler alanda Leydig hücre sayısının bol olduğu ve bağ dokusunun gelişmiş olduğu gözlendi (Resim: 1D).

Tübüllerin çaplarının gelişimi ile ilgili yapılan morfometrik ölçümlerde tübül çaplarının yaşa bağlı olarak giderek arttığı ancak 60 günden sonra artışın yatay bir seyir gösterdiği görüldü (Resim:2). Seminifer tübül çaplarının ölçümünde elde edilen değerler Tablo:1'de verilmiştir. Diğer yandan tübül çaplarının gruplar arasındaki değişimi istatistiksel olarak değerlendirildiğinde tübül çaplarındaki artışın 60. gün rat testisleriyle 90. gün rat testislerinde istatistiksel olarak anlamlı olmadığı ( $p=0.681)$, bunun dışında diğer tüm gruplar arasında değişimin istatistiksel olarak anlamlı olduğu (hepsi için $p \leq 0.001$ ) tespit edildi.

Deney grupları içindeki hayvanların seminifer tübülleri içinde bulunan kan-testis bariyerinin immunohistokimyasal incelenmesinde ise aşağıda belirtilen bulgular elde edildi.

Claudin 1 molekülü tight junctionlarda yer alan

Tablo I: Seminifer tübül çaplarının tanımlayıcı değerleri ( $\mu \mathrm{m})$. Tübül çapı

\begin{tabular}{|l|l|l|l|l|l|}
\hline & Öıçüm & & & & \\
\hline sayısı & Ortalama & Std. hata & Minimum & Maximum \\
\hline 14 gün & 120 & 81,86 &, 93845 & 55,03 & 106,90 \\
30 gün & 120 & 154,07 & 1,79737 & 110,70 & 217,80 \\
60 gün & 120 & 226,98 & 2,29416 & 167,50 & 296,90 \\
90 gün & 120 & 230,38 & 3,04771 & 157,30 & 324,70 \\
Total & 480 & 173,32 & 2,98665 & 55,03 & 324,70 \\
\hline
\end{tabular}

bir protein olup doku entegrasyonunda önemli rol oynar. İmmunohistokimyasal işaretleme sonrası yapılan ışık mikroskobik incelemelerde 


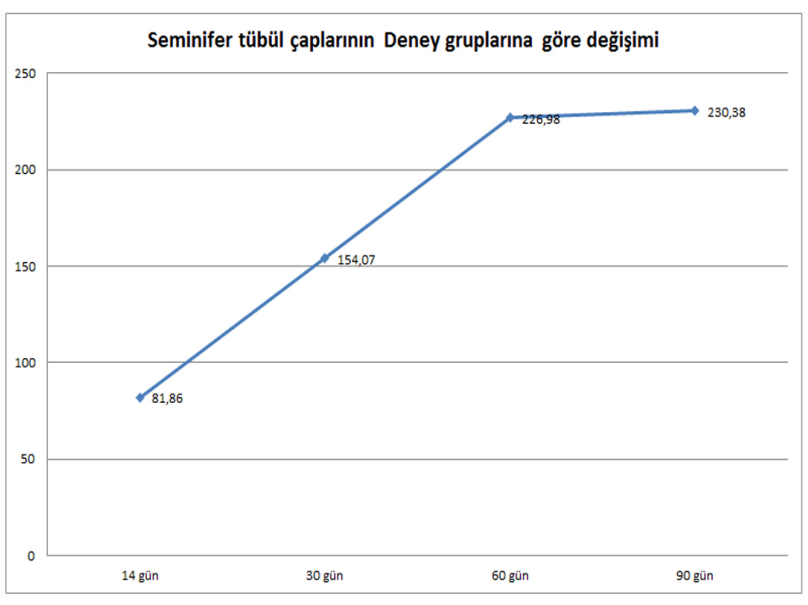

Resim 2: Seminifer tübül çaplarının deney gruplarına göre değişimi.

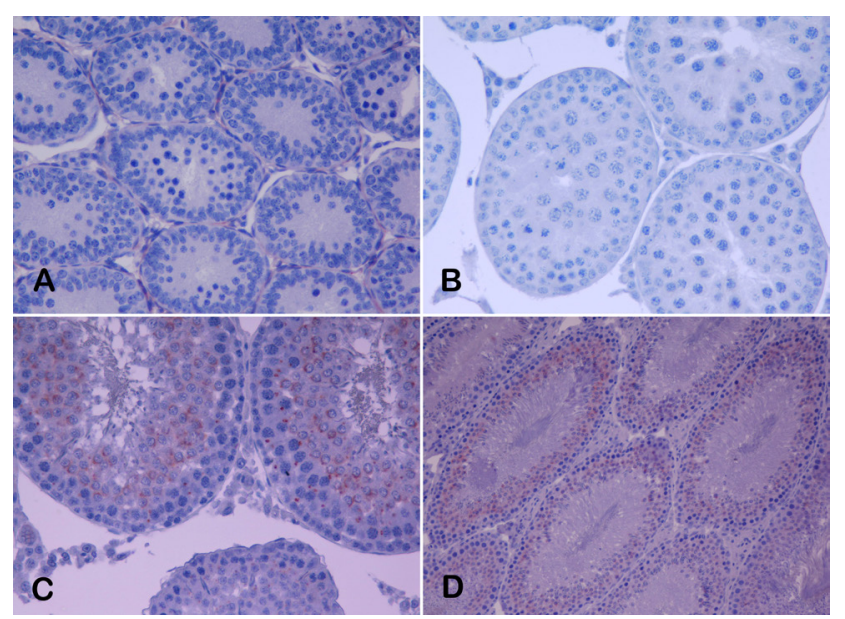

Resim 3: A. 14 günlük rat testisinde Klaudin primer antikoru ile boyanma sonucu ekspresyon görülmemektedir. (Anti-Klaudin. x40). B. 30 günlük rat testisinde Klaudin ekspresyonu (kiremit kırmızı boyanma görülen hücre zarları). (Anti-Klaudin. x60). C. 60 günlük rat testisinde Klaudin ekspresyonu (kiremit kırmızı boyanma görülen hücre zarları). (Anti-Klaudin. x60). D. 90 günlük rat testisinde Klaudin ekspresyonu (kiremit kırmızı boyanma görülen hücre zarları). (Anti-Klaudin. x40).

Claudin 1 ekspresyonunun 14 ve 30 günlük rat testislerinde seminifer tübüller içinde olmadığı gözlendi (Resim: 3A ve 3B). Ancak 60 ve 90 günlük dönemde olan ratlarda bilhassa tübüllerin orta kısımlarda belirgin olmak üzere ve spermatogenetik evre 7 üzeri tübüllerde Claudin 1 ekspresyonu olduğu tespit edildi (Resim: 3 C ve 3D).

Cadherin molekülü ise hücre yapışma molekülleri içinde yeralan ve hücreler arası entegrasyonu sağlamak suretiyle solid dokuların organizasyonunu sağlayan bir moleküldür. Yapılan immunohistokimyasal boyama sonrası ışık mikroskobik incelemelerde Cadherin ekspresyonunun 14 günlük rat testis seminifer tübüllerinde olmadığı 30 günlük ratlarda bilhassa lümene

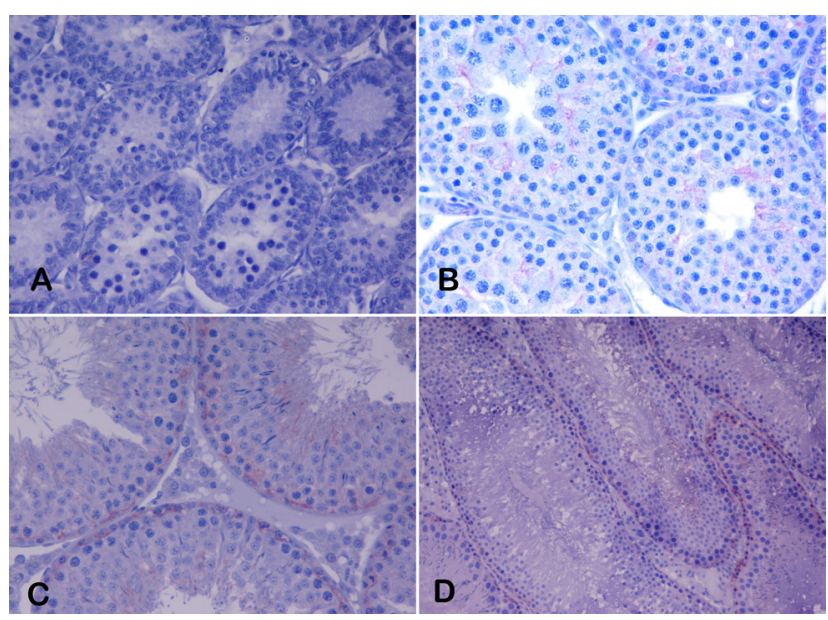

Resim 4: A. 14 günlük rat testisinde Kaderin primer antikoru ile boyanma sonucu ekspresyon görülmemektedir (Anti-Kaderin. x40). B. 30 günlük rat testisinde Kaderin ekspresyonu (kiremit kırmızı boyanma görülen hücre zarları) (Anti-Kaderin. x60). C. 60 günlük rat testisinde Kaderin ekspresyonu (kiremit kırmızı boyanma görülen hücre zarları) (Anti-Kaderin. x60). D. 90 günlük rat testisinde Kaderin ekspresyonu (kiremit kırmızı boyanma görülen hücre zarları) (Anti-Kaderin. x40).

yakın bölgelerde ortaya çıkmaya başladığı görüldü (Resim: 4A ve 4B). 60 ve 90 günlük ratlarda ise bilhassa seminifer tübül bazalindeki spermatogonialar arasında ve lümene yakın spermatidlerin çevresinde mevcut olduğu gözlendi (Resim: 4C ve 4D).

\section{TARTIŞMA}

Spermatogoniaların gelişim süreci içinde spermatogonialar bazal membrandan lümene doğru hareket gösterirler. Bu süreçte hücrelerin boyutu daha küçülür ve spermatid aşamasında ince uzun kuyrukları belirgin hale gelir ve baş kısmı fuziform bir hal alır. Lümene dökülmeden önce baş ve boyun kısımları iyice belirginleşir ve kuyruk hareketi başlar. Bununla birlikte, lümene geçen spermatozoa henüz oositi dölleme yeteneğine sahip değildir. Gerekli hareketin kazanılması ve hücrenin yapısının olgunlaşması için epididim içinde uzun bir yolculuk gerekir. Bu dönemde epididim epitelinde yer alan stereosilyalar spermatozoaların olgunlaşmasında fiziksel ve metabolik destek sağlar$\operatorname{lar}(2,3)$. Ratlar üzerinde yapılan bir çalışmada spermlerin üretiminin ilk defa doğum sonrası 45. günde görüldüğü ancak optimum üretimin 75. günden itibaren gerçekleştiği gösterilmiştir (7). Ancak bu dönem içinde spermatogonialar lümen içinde yerleşik haldedir ve bazıları spermatogenezis sürecini geçirmeye başlar. Bahsedilen süreler ilk olgun spermin oluştuğu zaman 
olarak tanımlanabilir. Aynı şekilde ratlardaki puberteye girme yaşının, kardeş sayısı, hormonal durum ve beslenme gibi faktörlerden dolayı değişebildiği ve seksüel olgunluk dönemlerinin doğum sonrası 65.-110. günler arasında olduğu bildirilmiştir (8). Yapılan değişik çalışmalarda spermatogenetik süreç morfolojik anlamda oldukça iyi anlaşılmış olmasına karşın moleküler düzeyde görülen değişikliklerle ilgili veriler her gün gelişmekte ve güncellenmektedir. Yapılan başka bir çalışmada spermatogenezis sırasında gelişmekte olan germ hücrelerinin bazal kısımdan seminifer epitelin adluminal kompartmanına doğru göç ederek ilerlediği ve bu süreçte spermatogonialar ve Sertoli hücreleri arasında hücre-hücre arayüzünün yeniden yapılandığını göstermişlerdir (9). Yaptığımız çalışmada da genel olarak yaptığımız değerlendirmede spermatogonialardan spermatozoalara dönüşümde daha önce yapılan çalışmalara benzer şekilde gelişen haftalar içerisinde bazal membrandan lümene doğru bir ilerlemenin olduğu ve bu süreçte spermatogonialar ile Sertoli hücreleri ile aralarında yer alan bağlantı komplekslerinde yapısal değişim ve olgunlaşma olduğu gözlenmiştir.

Yapılan değişik anatomik, morfolojik ve morfometrikçalışmalarda testisleringelişiminde ilerleyen aylara bağlı parallel bir artış olduğu ancak özellikle puberte dönemi civarında gerek seminifer tübül çaplarında, gerek hücre sayısı ve çeşitliliğinde ve gerekse organizasyon hızlı bir gelişimin hızlandığı gözlenmiştir $(10,11,12)$. Bizim çalışmamızda da 14 günlük ratların seminifer tübüllerinin incelenmesinde tübüllerin çaplarının oldukça dar, lümenlerin oluşmamış ve bazal kısımda yerleşik çok sayıda spermatogonia olduğu görülmüştür. Hatta normal histolojik incelemelerde tanımlanması zor olan Sertoli hücrelerinin lümen içinde soluk çekirdekleri ve saydam sitoplazmalarına rağmen çok belirgin bir şekilde ayırt edilebildiği gözlendi ve bu süreçte herhangi bir spermatid oluşumu söz konusu olmadığı için spermatogenezin başlamamış olduğu kabul edildi. Diğer yandan Leydig hücrelerinin sayısının intertübüler alanda az sayıda olduğu ve bu dönem içerisinde spermatogenetik evrelendirmelerin incelenmesi sonucunda hiçbir spermatogenetik aktivasyon olmadığı gözlendi.

Otuz günlük ratların testislerinin incelenmesinde ise seminifer tübül çaplarının 14 günlük rat testis tübüllerine göre anlamlı şekilde arttığı gözlendi. Seminifer tübüllerin histolojik incelemesinde spermatogonia sayısında artış ve $B$ tipi spermatogoniaların belirginleştiği görüldü. Bununla birlikte, Sertoli hücrelerinin tübül içinde daha seçilemez hale geldiği ve sayılarının spermatogoniaların sayısına göre, 14 günlük rat testisleriyle karşılaştırıldığında, azaldığı gözlendi. Bu azalmanın daha önce bahsettiğimiz gibi artan spermatogonia sayısına bağlı olarak Sertoli hücre sayısının tübül içi toplam hücre sayısına oranındaki azalmayla ilişkili olduğu şeklinde yorumlandı. Lümenin incelenmesinde henüz birçok tübülde lümen şekillenmesinin olmadığı gözlendi. Bunun yanında bazı tübüllerin lümene yaklaşık bölgelerinde oldukça az sayıda spermatidin mevcut olduğu gözlendi. 30 günlük ratların testislerinde intertübüler alanda yapılan değerlendirmede, bu bölgedeki Leydig hücrelerinin sayısında ve bağ dokusu hacminde artış olduğu ve bağ dokusunun daha organize görünümdde olduğu gözlendi. Bu döneme ait spermatogenetik evrelendirme evre 1-3 arasında olduğu gözlendi $(1,3)$.

Altmış günlük ratların testislerinin histolojik incelenmesinde ise tübüllerin histolojik organizasyonlarını tamamladıkları, bazal membran üzerinde açık renkli sitoplazmalarıyla iri A tipi spermatogonialar ve onların daha iç kesiminde kromatin ağı belirgin hiperkromatik çekirdekleriyle B tipi spermatogonialar ve lümene yakın yerlerde çok sayıda yuvarlak ve fuziform spermatidler olduğu ve spermatidlerin kuyruklarının lümene doğru adeta at kuyruğu gibi sarkmış halde olduğu görüldü. Bununla birlikte bu yüksek evreli tübüllerin yanında düşük evreli tübüllerin de mevcut olduğu, buralarda spermatid sayısının daha az olduğu gözlendi. Sertoli hücrelerinin hemen hemen hiç seçilemediği ancak dikkatle bakıldığında hücre zarlarının uzantılarının olduğu dikkat çekiyordu. Sertoli hücre sayısının tübül için tüm genel hücre po- 
pülasyonuna göre belirgin derecede azalmış olduğu görüldü. Tübüllerin çaplarının 30 günlük rat testis tübüllerine göre anlamlı şekilde arttığı tespit edildi. İntertübüler alanda Leydig hücreleri sayısı artmış ve bağ dokusu iyi yapılanmış durumdaydı. Çalışmamızın evrelendirmeleri incelendiğinde ise bu dönemde tüm tübüllerde spermatojenik aktivasyonun olduğu, her evreye ait çok sayıda tübül olduğu ve tübül içlerinin değişik evrelerde bulunan germ hücreleri ile dolu oldukları görüldü.

Doksan günlük olan ergin ratların testislerinin incelenmesinde ise tübül çaplarının 60 günlük rat testislerine göre istatistiksel anlamda anlamlı olmayacak şekilde arttığı, tübül içi ve dışındaki hücre dağılımı ve organizasyonunun 60 günlük ratların hemen hemen hepsinde tamamen aynı olduğu sadece evresi yüksek tübül sayısının biraz daha fazla olduğu görüldü. Diğer yandan intertübüler alandaki histolojik özelliklerinde ve evrelendirme değerlendirmesinde 60 günlük ratlar ile aynı olduğu belirlendi.

Kan-testis bariyerinin rutin histolojik örneklerde görülebilmesi mümkün değilken bu bariyeri oluşturan moleküler komponentlerin işaretlenmesi ile yapısı hakkında önemli bilgiler edinilmektedir. Bu amaçla kullanılan en yaygın işaretleme metodlarının başında immunohistokimyasal boyamalar gelmektedir. Yapılan ileri analizler ve elektron mikroskobik incelemeler sonrası kan-testis bariyerini oluşturan komponentlerin hücreler arasında bağlantı kompleksleri ve hücre yapışma molekülleri olduğu anlaşılmıştır. Bu yapılar hücreleri birbirine ve bazal membrana tutundurmak için bazolateral yüzlerde bulunur. Hücre yapışma (adezyon) molekülleri Ca2+ bağımlı moleküller olan Cadherinler ve selektinlerin dahil olduğu proteinler, $\mathrm{Ca} 2+$ bağımsız moleküller olan immünglobulin süper ailesi ve integrinlerdir. İntegrinler temel olarak hücre-hücrelerarası matriks etkileşiminde önemlidir. Cadherinler ve integrinler hücre iskeleti ile diğer hücrede yer alan Cadherinlerle ya da hücre dışı matriks (integrinler) ile bağlantı kurar. Hücreler arasındaki bağlantılar karşılıklı iki hücrede yerleşmiş simetrik yapılardır $(2,5)$. Kan-beyin bariyeri, kan-retina bariyeri gibi apikal bölgedeki kılcal endotel hücreleri arasındaki tight junction'lar tarafından oluşturulan kan-doku bariyerlerinin aksine, kan-testis bariyeri bazal membran yakınında bulunan seminifer epitelyumdaki Sertoli hücreleri tarafından oluşturulur $(14,15)$. Tight junction hücreler arasındaki boşluklar aracılığıyla moleküllerin polaritesini tanımlayan bir sınır oluşturarak bir epitel ya da endotel bariyer teşkil eden tek örnektir (3). Tight junctionlarda Claudin grubu moleküller ve Occludin molekülleri bulunur ve bunlar immun işaretleme yöntemleriyle görülebilir duruma getirilir (4). Tight junctionların testislerde oluşturdukları bağlantılar sonucu oluşan kan-testis bariyerinin gelişiminde önemli bir molekül olan Claudin grubundan günümüze dek en çok üzerinde çalışılan Claudin 11 'dir (13-16). Bununla birlikte çalışmamızda diğer çalışmalardan farklı olarak Claudin 1 çalışılmış olup, bu proteinle ilgili daha önce kan-testis bariyerinde yeri ve önemi ile ilgili kaynağa rastlanmaması çalışmamızın literatüre önemli katkılarından biri olacaktır. Diğer yandan hücre yapışma molekülleri içinde yer alan Cadherinlerin spermatogonial süreçteki etkileri de oldukça az çalışılan bir konu olup daha çok kateninle etkileşimi incelenmiştir. Çalışmamız bu nedenle Cadherinlerin ekspresyonunun spermatogenetik süreçte incelendiği ilk çalışmalardandır. Çalışmamızda bu proteinler 30, 60 ve 90 günlük rat gruplarında ortaya konmakla birlikte 15 günlük ratlara ait testislerde kan-testis bariyerinin yapılanmadığını tespit edilmiştir. Bu bakımdan kan-testis bariyeri oluşumunun intrauterin dönemde tamamlanan bir süreç olmadığı, doğum sonrası dönemde tam olarak şekillenmeye başladığını düşünmekteyiz.

Elde edilen sonuçlar ratlarda spermatogenetik sürecin intrauterin hayatta başlamadığı ve hatta doğum sonrası 14. günde bile mevcut olmadığını göstermektedir. 30. günden kısa süre önce başladığını düşündüğümüz spermatogenetik sürecin yaşa bağımlı bir paralellik gösterdiği ortaya konmuş olup fonksiyonel anlamda testis yapılanmasının 60 günlük ratlarda mevcut olduğu tespit edilmiştir. Bununla birlikte elde edilen bu yapılanma bulgularının ilerleyen günlerde fazla değişiklik göstermediği de belirlenmiştir. 
Diğer yandan kan-testis bariyerinin de incelendiği çalışmamızda kan-testis bariyerinin 14 günlük rat testislerinde henüz oluşmadığı, 30. günde yavaş yavaş belirginleşmeye başladığı ve 60 . gün ile sonrası ratlarda yapılanmanın tamamlandığı tespit edilmiştir. Çalışmamızda diğer çalışmalardan farklı olarak üzerinde az çalışılmış olması nedeniyle Claudin 1'inde testislerin gelişimsel sürecinde etkin önemli faktörler içinde olduğu belirlenmiştir.

\section{EK BILLGi}

Bu bilimsel makale Hüsniye Karateke isimli Afyon Kocatepe Üniversitesi Tıp Fakültesi Anatomi Anabilim Dalı Yüksek Lisans öğrencisinin 2013 - 005 (Afyonkarahisar-2013) Tez No'lu tezinden üretilmiştir.

\section{REFERENCES}

1. Hess Ra and Franca L. Spermatogenesis and Cycle of the Seminiferous Epithelium In: Molecular Mechanisms in Spermatogenesis (Ed: Cheng CY). Landes Bioscience and Springer Science+Business Medicine LLC, Texas USA. 2008:1-14.

2. Kıerszenbaum AL. Spermatogenesis In: Histoloji ve Hücre Biyolojisi (Patolojiye Giriş) Çeviri Ed: Prof. Dr. Demir R. 1.baskı, Ankara: Palme Yayıncılık, 2006:531-550.

3. Xiao X, Mruk DD and Cheng CY. C-Yes regulates cell adhesion at the apical ectoplasmic specialization-blood-testis barrier axis via its effects on protein recruitment and distribution. Am J Physiol Endocrinol Metab. 2013; 304(2):145-59.

4. Alberts B, Johnson A, Lewis J et al. Germ Hücreleri ve Döllenme In: Hücrenin Moleküler Biyolojisi, 4.baskı, Ankara: Sistem Ofset Basım Yayın San. Tic. Ltd. Şti, 2008:1127-1156.

5. Su W, Mruk DD, Cheng C. Filamin A, A regulator of bloodtestis barrier assembly during post-natal development. Spermatogenesis. 2012;2(2): 73-78.

6. Mok KW, Mruk DD, Lee WM et al. A study to assess the assembly of a functional blood-testis barrier in developing rat testes. Spermatogenesis. 2011;1(3):270-280.

7. Mülazımoğlu SB, İdeT ve Aslan S. Küçük Deney Hayvanlarından Rat (Ratlarda Üreme), Ankara: Matris Tanıtım Baskı Hizmetleri, 2012.

8. Soylu SM, Küçük Deney Hayvanlarından Rat (Rat Fizyolojisi), Ankara: Matris Tanıtım Baskı Hizmetleri, 2012.

9. Storey BT. Sperm capacitation and the acrosome reaction, Annals of the New York Academy of Sciences. 1991;Volume 637: 459-473.

10. Tosun M. İnsan Gonadlarının İntrauterin Gelişiminin Histolojik Değerlendirilmesi, Selçuk Üniversitesi Sağlık Bilimleri Enstitüsü, Histoloji Embriyoloji (TIP) Anabilim Dalı, Doktora TeziKonya, 1998.
11. Antony $C T$, Glenn $B K$ and Skinner $M K$. Effect of an extracellular matrix on the hormonal regulation Sertoli cell function, Cell Biology of the Testis and Epididymis, Ann of the NY Acad of Sciences. 1987; Volume 513, 413-414.

12. Mruk DD, Cheng CY Sertoli-Sertoli and Sertoli-Germ Cell Interactions and Their Significance in Germ Cell Movement in the Seminiferous Epithelium during Spermatogenesis, Endocrine Reviews. 2004;25(5):747-806.

13. Yılmaz A Spermatogonial Kök Hücreleri ve Transplantasyonu (Spermatogonial stem cells and transplantation). Ege Üniversitesi Ziraat Fakültesi Dergisi. 2009;46 (2): 145-154.

14. Morrow $C M$, Tyagi $G$, Simon $L$ et al. Claudin 5 Expression in Mouse Seminiferous Epithelium Is Dependent upon the Transcription Factor Ets Variant 5 and Contributes to BloodTestis Barrier Function. Biol Reprod. 2009;81(5):871-879.

15. Li MW, Mruk DD, Lee WM et al. Connexin 43 is critical to maintain the homeostasis of the blood-testis barrier via its effects on tight junction reassembly. Proc Natl Acad Sci USA. 2010;19;107(42):17998-8003.

16. Florin A, Maire M, Bozec A et al. Androgens and postmeiotic germ cells regulate claudin-11 expression in rat Sertoli cells. Endocrinology. 2005;146(3):1532-40. 